Who pays if the oil destroys the marshes entirely?

The 1989 Exxon Valdez oil spill in Alaska raised similar questions, and sparked a flurry of research in the once-obscure discipline of ecological economics, which seeks to estimate quantities such as the 'replacement cost' of an ecosystem - or even an individual organism. (Killer whales cost $\$ 300,000$ at the time; cormorants were a bargain at $\$ 310$ apiece.) The Gulf oil spill seems likely to inspire another surge of research in this field. Indeed, ecological economist Robert Costanza at the University of Vermont in Burlington has already estimated a \$34-billion to \$670-billion price tag for the loss of Gulf ecosystem services.

Costanza also has a suggestion for how to avoid such harm in the future: force companies that want to drill, dig or otherwise extract resources to take a more serious account of environmental risks before they start. He and his colleagues have argued that the best way to do this is to demand that each company put up an "assurance bond": a sum of money large enough to rectify damages if things go wrong (see go.nature.com/styAyz). The amount of the bond would be set by an independent government agency or government-chartered body, and be based on the total value of the ecosystems at risk. In BP's case, Constanza says, the company would have had to put up something like $\$ 50$ billion to get permission to drill in the Gulf, or about two to three times the $\$ 20$ billion they are having to pay now. The very size of that bond, in turn, might have made the company more likely to invest, say, $\$ 500,000$ in a functional blowout preventer.

Other experts favour a variant of this idea in which large, risky enterprises would be required to carry insurance against ecosystem services claims - an approach that would essentially put the insurance companies in charge of policing safety practices.

These and other variants seem well worth exploring as a way to bring ownerless ecosystem services into the marketplace. Congress and the US administration should take the idea seriously. But the science behind putting a price on nature must also improve. After all, any attempt to extract a multi-billion-dollar compensation for ecosystem damage seems likely to wind up in court. So scientists' cost estimates will have to be sound enough to convince judges and juries, not just make for an interesting journal article.

Such an increase in rigour is hardly bad news for research. If ecosystems services science gets a boost from the spill, that may be one of the few silver linings to the dark plume that continues to gush in the Gulf of Mexico.

\section{The right kind of elitism}

\section{National academies can be pivotal in speaking up for science, both to those in power and to the public.}

B ritain's Royal Society is 350 years old this year, and its track record is one worthy of celebration. It stands today as a relatively successful model of what an independent national academy can achieve, having made itself both highly regarded in the corridors of power and prominent in public debates on major science-related issues (see pages 1002 and 1009).

Such success cannot be taken for granted. In many parts of the world, scientific academies either lack real independence from the state (as in China) or else struggle to make themselves heard within it (as in Italy). And even where academies have established an independent voice - other notable examples include those in the United States, the Netherlands and Sweden - they must still maintain the difficult balance between taking stances that are full-throated enough to make the news, yet not so rash as to tarnish their reputation for impartiality.

As the Royal Society has demonstrated, however, scientific academies able to navigate these treacherous waters can offer authoritative input on contentious public-policy issues such as climate change, or the regulation of human embryonic stem-cell research, and can thus enrich public debate by ensuring that science is properly heard.

Sometimes that input will be articulated through technical reports, such as those produced in large numbers by the US National Academy of Sciences through its operating arm, the National Research Council. Academies also exert influence through informal consultation with government officials, and by influencing the selection of their government's scientific advisers.

But these traditional avenues are only part of what academies can do to exert influence today. They can also issue more concise statements for wider audiences. And they can proactively engage with the public and the media in the same way that corporations and environmental pressure groups do - by anticipating or responding rapidly to events, and making sure that science's voice is heard amid the general cacophony.

The Royal Society has, in recent years, used this kind of engagement to good effect. Academies that are seeking similar impact, such as new and reconstituted ones in Africa and the Leopoldina, which assumed the official status of Germany's national academy only three years ago, need to be similarly bold and outward-looking in their approach.

Their memberships should note, however, that in order to have an independent voice, at least some of their funding must come from non-government sources. To exert influence, they must also carefully nurture connections with people and institutions inside government who genuinely want independent scientific input - and who can tell the difference between such advice and propaganda. Without that audience, no amount of earnest objectivity will establish a place for a scientific academy inside the framework of a state.

And even successful academies need to keep an eye on their own processes, and resist the opaqueness and cliquishness that can afflict any self-appointed club. Ten years ago, for example, the US National Academy of Sciences staunchly resisted what it now concedes were positive advances in the transparency of its processes. And just recently it has noticed that Asian-Americans, who have become ubiquitous in American universities, are largely absent from its own ranks.

Academies can still have a crucial role in taking scientific truth to the public, and to the heart of government. But to do so, they must constantly strive to properly represent an increasingly diverse scientific community. And they must adapt their processes and actions to a political and media landscape that doesn't sit still for 350 minutes, never mind 350 years. 